\title{
The role of bacteria in lactational mastitis and some considerations of the use of antibiotic treatment Linda J Kvist* ${ }^{\dagger 1,2}$, Bodil Wilde Larsson ${ }^{\dagger 2}$, Marie Louise Hall-Lord ${ }^{\dagger 2,3}$, Anita Steen ${ }^{\dagger 4}$ and Claes Schalén ${ }^{\dagger 4}$
}

Address: ${ }^{1}$ Department of Obstetrics and Gynaecology, Helsingborg Hospital, 251 87, Sweden, ${ }^{2}$ Department of Nursing, Karlstad University, 651 88 , Sweden, ${ }^{3}$ Department of Nursing, Gjovik University College, Norway and ${ }^{4}$ Department of Clinical Microbiology and Immunology, University Hospital, Lund, Sweden

Email: Linda J Kvist* - linda.kvist@skane.se; Bodil Wilde Larsson - bodil.wilde@kau.se; Marie Louise Hall-Lord - marie-louise.hall-lord@kau.se; Anita Steen - anita.steen@skane.se; Claes Schalén - claes.schalen@med.lu.se

* Corresponding author †Equal contributors

Published: 7 April 2008

International Breastfeeding Journal 2008, 3:6 doi:10.1 186/I746-4358-3-6
Received: 6 December 2007

Accepted: 7 April 2008

This article is available from: http://www.internationalbreastfeedingjournal.com/content/3/1/6

(c) 2008 Kvist et al; licensee BioMed Central Ltd.

This is an Open Access article distributed under the terms of the Creative Commons Attribution License (http://creativecommons.org/licenses/by/2.0), which permits unrestricted use, distribution, and reproduction in any medium, provided the original work is properly cited.

\begin{abstract}
Background: The role of bacterial pathogens in lactational mastitis remains unclear. The objective of this study was to compare bacterial species in breast milk of women with mastitis and of healthy breast milk donors and to evaluate the use of antibiotic therapy, the symptoms of mastitis, number of health care contacts, occurrence of breast abscess, damaged nipples and recurrent symptoms in relation to bacterial counts.
\end{abstract}

Methods: In this descriptive study, breast milk from 192 women with mastitis (referred to as cases) and 466 breast milk donors (referred to as controls) was examined bacteriologically and compared using analytical statistics. Statistical analyses were also carried out to test for relationships between bacteriological content and clinical symptoms as measured on scales, prescription of antibiotics, the number of care contacts, occurrence of breast abscess and recurring symptoms.

Results: Five main bacterial species were found in both cases and controls: coagulase negative staphylococci (CNS), viridans streptococci, Staphylococcus aureus (S. aureus), Group B streptococci (GBS) and Enterococcus faecalis. More women with mastitis had S. aureus and GBS in their breast milk than those without symptoms, although $31 \%$ of healthy women harboured S. aureus and $10 \%$ had GBS. There were no significant correlations between bacterial counts and the symptoms of mastitis as measured on scales. There were no differences in bacterial counts between those prescribed and not prescribed antibiotics or those with and without breast abscess. GBS in breast milk was associated with increased health care contacts $(p=0.02)$. Women with $\geq 10^{7} \mathrm{cfu} / \mathrm{L}$ CNS or viridans streptococci in their breast milk had increased odds for damaged nipples $(p=0.003)$.

Conclusion: Many healthy breastfeeding women have potentially pathogenic bacteria in their breast milk. Increasing bacterial counts did not affect the clinical manifestation of mastitis; thus bacterial counts in breast milk may be of limited value in the decision to treat with antibiotics as results from bacterial culture of breast milk may be difficult to interpret. These results suggest that the division of mastitis into infective or non-infective forms may not be practically feasible. Daily follow-up to measure the subsidence of symptoms can help detect those in need of antibiotics. 


\section{Background}

Appropriate treatment for inflammatory symptoms of the breast in lactating women has been under discussion in the scientific literature for some time. One reason why consensus has not been reached is that the clinical spectrum of "mastitis" covers a range from focal inflammation with minimal systemic response to septicaemia [1]. According to a review by the World Health Organization (WHO), the incidence of mastitis varies greatly, from $2.6 \%$ to $33 \%$, among breastfeeding women [2]. This suggests that due to difficulties in the definition of the term "mastitis" [3], researchers might not have been investigating comparable groups of women. Furthermore, the lack of internationally agreed scales for the measurement of symptoms creates difficulties in the use of meta-analyses.

The role of bacterial pathogens in lactational mastitis is unclear [1-4]. In the 1980s, Thomsen et al suggested that levels $>10^{6} \mathrm{cfu} / \mathrm{L}$ of pathogenic bacteria in breast milk was an indication for antibiotic treatment since this level, together with leukocytosis was indicative of infection $[5,6]$. Others have suggested that untreated cases may recover as quickly as treated cases [7] and that bacteriological examination of breast milk may be of limited value [8].

The aims of this study were to compare bacterial species in breast milk of mothers with mastitis and of healthy breast milk donors and to evaluate in relation to bacterial counts, the use of antibiotic therapy, the symptoms of mastitis as measured on scales, number of health care contacts, occurrence of breast abscess, occurrence of damaged nipples and recurrence of symptoms.

\section{Methods \\ Study population}

The case group consisted of 205 women who contacted a breastfeeding clinic in southern Sweden during 2002 2004 because of inflammatory symptoms of the breast during lactation and had agreed to join a randomised controlled trial of care interventions [4]; registration number of the RCT is: NCT00405158. The incidence of mastitis in the uptake area was estimated as $6 \%$ of the breastfeeding population [4]. Of the 205 women, 192 (94\%) had their breast milk sampled and sent for bacteriological investigation. A follow-up questionnaire inquiring about recurrent symptoms and the women's views on care given was sent by post to the cases, six-weeks following their last contact with the breastfeeding clinic. A total of 176 (84\%) returned the questionnaire.

The control group consisted of 466 healthy, prospective breast milk donors living in the same geographical area as the case group and studied during the same period of time. According to Swedish recommendations, women with an established lactation who wish to donate breast milk for use in neonatal units are obliged to leave milk for bacterial analysis before being accepted as donors.

\section{Ethical considerations}

Ethical approval for the randomised controlled trial (RCT) was granted by the Committee for Medical Research Ethics, Lund University Hospital, Sweden (protocol number LU 592-00). Two of the authors (CS and AS) are employed at the laboratory where the specimens are tested and therefore had access to the material. After analysis of milk samples and reporting of results to the neonatal units who submitted the samples, a database, without any means of identification of individual samples was set up. Since personal data of the controls were unknown to the researchers, results of their breast milk cultures could not be traced to individuals.

\section{Signs and symptoms of breast inflammation}

Women were considered to have mastitis when at least two of the following signs or symptoms were present: breast erythema, increased breast tension not relieved by breastfeeding, maternal fever, pain in the breast and lumps in the breast tissue [4]. A midwife at the breastfeeding clinic carried out the initial measurement of signs and symptoms together with the woman. Scores for these signs and symptoms were estimated on scales, which were tested for internal consistency using Cronbach's alpha [9]. The alpha score on contact day three was $0.79[4,10]$. Scores were added to create a Severity Index (SI), range 0 (least severe) to 19 . Table 1 shows the values for the scales. At subsequent daily telephone follow-ups, the women were asked to report their scores in relation to their scores

Table I: The scales used for the measurements of mastitis signs and symptoms in the RCT

\begin{tabular}{ll}
\hline Erythema & Breast tension \\
\hline No redness $=0$ & No change $=0$ \\
Slight redness in limited area $=1$ & Firm, no tenderness $=1$ \\
Redness in limited area $=2$ & Tense, not uncomfortable $=2$ \\
Bright red in limited area $=3$ & Tense and uncomfortable $=3$ \\
Bright red over most of the breast $=4$ & Tense and painful $=4$ \\
& Very tense and very painful $=5$
\end{tabular}

Pain was measured by Visual Analogue Scale: $0=$ no pain, $10=$ worst possible pain. Severity Index $=$ Erythema + Breast tension + Pain: range $0-19$ 
on the previous day. The same midwife carried out the telephone follow-ups as far as possible but this was not always the case. The number of midwives involved in the study was seven.

\section{Collection of samples}

Both cases and controls were asked to provide a sample of breast milk for bacterial culture and the samples were all examined at the same laboratory. The nipple and areola of the affected breast was cleaned with normal saline solution; the woman was given non-sterile surgical gloves and asked to manually express several drops of milk, which were discarded before collecting the specimen directly into the test tube. In cases of bilateral symptoms (14\%), milk was sampled from the breast which was most affected. The controls provided a sample of milk pooled from both breasts. In the case group, the women were informed that the results of culture would be available after two to three days, by which time it was expected that they would be on the way to recovery. A sample of breast milk was obtained from each of the 192 cases and all 466 of the control subjects.

\section{Bacteriological analysis of breast milk}

Breast milk samples were refrigerated until transport to the laboratory within 24 hours. Tenfold dilutions of milk were plated on horse blood agar (HBA) and incubated at $37^{\circ} \mathrm{C}$ aerobically for two days. Bacterial species were quantified and identified according to standard methods.

\section{Statistical analysis}

The material was analysed using SPSS version 14.0 (SPSS, Inc., Chicago, USA). Five main bacterial species occurred in sufficient numbers of specimens to allow statistical comparisons between cases and controls. Odds Ratios (OR) with 95\% confidence intervals (CI) were calculated for the occurrence of mastitis for each of these species. Pearson's correlation test was used to assess possible correlations between bacterial counts and symptoms at first contact: maternal temperature, breast erythema, increased breast tension, pain and SI (0-19). Differences in mean bacterial counts between cases who received or did not receive antibiotics and between those with and without abscess were assessed using the independent samples ttest. In accordance with the level of bacterial content described by Thomsen et al $[5,6]$ variables for the five main bacterial species in the mastitis group were dichotomised to $\leq 10^{6} \mathrm{cfu} / \mathrm{L}$ milk and $\geq 10^{7} \mathrm{cfu} / \mathrm{L}$ milk. Odds Ratios with $95 \%$ confidence intervals were then calculated for the proportions of cases with higher or lower levels of the five bacterial categories $v s$. prescription of antibiotics, occurrence of residual symptoms within six weeks and for the occurrence of damaged nipples. The independent samples t-test was used to assess whether those with any one of the five main bacterial species in breast milk required prolonged contact with the breastfeeding clinic. Significance was assumed at the 0.05 level.

\section{Results \\ Comparison of bacterial findings in cases and controls}

Microbiological findings are summarized in Table 2. The five main bacterial species found in cases and controls were coagulase negative staphylococci (CNS), viridans streptococci, Staphylococcus aureus (S. aureus), Group B streptococci (GBS) and Enterococcus faecalis. CNS were detected significantly more often in the milk of the healthy controls than among cases (OR: 0.60, 95\%CI: $0.35,0.91)$. In contrast, three of the other species were present significantly more often among cases than controls: viridans streptococci: (OR: 1.43, 95\%CI: 1.02, 2.01) S. aureus: (OR: $1.81,95 \% \mathrm{CI}: 1.29,2.60)$ and GBS: (OR: 2.40, 95\%CI: $1.50,3.71)$.

\section{Correlations between symptoms and bacterial counts}

There were no significant correlations between bacterial counts of the five main species in the breast milk and maternal temperature, breast erythema, breast tension, pain, or the Severity Index at first contact (Table 3).

\section{Bacteria and number of contact days with breastfeeding clinic}

Occurrence of GBS in the breast milk was associated with a significant increase in the number of contact days with the breastfeeding clinic $(\mathrm{t}=-2.44, \mathrm{p}=0.02)$. In contrast, presence of CNS, viridans streptococci or $S$. aureus did not affect the number of health care contact days.

\section{Antibiotic therapy, breast abscess, recurrence of symptoms and damaged nipples in relation to bacterial counts}

Seven of the women (3.3\% of the cases) were prescribed antibiotics on the basis of their symptoms alone, before results of bacterial cultures were available. A total of 24 $(11.4 \%)$ cases were prescribed antibiotics on the basis of culture results, including those who developed a breast abscess during contact with the breastfeeding clinic. Thus, a total of $31(15 \%)$ women in the case group received antibiotic treatment. Table 4 shows the outcome of culture from the breast milk of women who were prescribed antibiotics on the basis of symptoms alone and women who developed a breast abscess during contact with the breastfeeding clinic. Among the cases there were no significant differences in bacterial counts of those given $(\mathrm{n}=$ 31) vs not given $(\mathrm{n}=161)$ antibiotics or those with $(\mathrm{n}=$ 7) $v s$ without a breast abscess $(\mathrm{n}=185)$. Less than half $(42 \%)$ of the 31 women who were given antibiotics had $S$. aureus in their breast milk. The odds for damaged nipples was increased when $\geq 10^{7} \mathrm{cfu} / \mathrm{L}$ of CNS or viridans streptococci was present in the breast milk: CNS: OR: 2.51 (95\%CI: 1.33, 4.61) and viridans streptococci: OR: 2.54 (95\%CI: 1.34, 4.90). 
Table 2: Bacterial findings in breast milk of women with and without symptoms of mastitis: Odds Ratios with $95 \%$ confidence intervals for symptoms of mastitis

\begin{tabular}{|c|c|c|c|c|c|}
\hline \multirow[b]{2}{*}{ Bacterial Species } & \multicolumn{2}{|l|}{ Healthy donors $(n=466)$} & \multicolumn{3}{|c|}{ Women with mastitis $(n=192)$} \\
\hline & $\begin{array}{l}\text { Occurrence of bacteria } \\
\text { in breast milk } n(\%)\end{array}$ & $\begin{array}{l}\text { Mean (SD) counts } \\
\text { (cfu/L) }\end{array}$ & $\begin{array}{l}\text { Occurrence of bacteria in } \\
\text { breast milk } n(\%)\end{array}$ & $\begin{array}{l}\text { Mean (SD) counts } \\
\text { (cfu/L) }\end{array}$ & $\begin{array}{l}\text { Odds Ratio for } \\
\text { occurrence of mastitis } \\
\text { symptoms }(95 \% \mathrm{Cl})\end{array}$ \\
\hline CNS & $419(90 \%)$ & $10^{6( \pm 1.1)}$ & $160(83 \%)$ & $10^{6( \pm 1.1)}$ & $\begin{array}{l}0.60(0.35,0.91) \\
P=0.02\end{array}$ \\
\hline Viridans Streptococci & $233(50 \%)$ & $10^{5( \pm 1.0)}$ & $113(59 \%)$ & $10^{5( \pm 1.0)}$ & $\begin{array}{l}1.43(1.02,2.01) \\
p=0.04\end{array}$ \\
\hline Staphylococcus aureus & 145 (31\%) & $10^{6( \pm 1.2)}$ & $87(45 \%)$ & $10^{6( \pm 1.3)}$ & $\begin{array}{l}I .81(1.29,2.60) \\
P=0.00 \mid\end{array}$ \\
\hline Group B streptococci & $47(10 \%)$ & $10^{6( \pm 1.5)}$ & $4 \mid(21 \%)$ & $10^{6( \pm 1.4)}$ & $\begin{array}{l}2.40(I .50,3.7 I) \\
P=<0.00 I\end{array}$ \\
\hline Entercoccus faecalis & $28(6 \%)$ & $10^{6( \pm 1.1)}$ & $16(8 \%)$ & $10^{6( \pm 1.1)}$ & $\begin{array}{l}0.70(0.36,1.43) \\
P=0.36\end{array}$ \\
\hline Group G streptococci & $6(1 \%)$ & $10^{6}$ & $3(2 \%)$ & $10^{7}$ & \\
\hline Group A streptococci & $3(1 \%)$ & $10^{7}$ & $2(1 \%)$ & $10^{7}$ & \\
\hline Pneumococci & $4(1 \%)$ & $10^{7}$ & $5(3 \%)$ & $10^{5}$ & \\
\hline Corynebacteria & $2(0.4 \%)$ & $10^{4}$ & I (0.5\%) & $10^{5}$ & \\
\hline Enterobacteriaceae & $36(8 \%)$ & $10^{6}$ & $2(1 \%)$ & $10^{6}$ & \\
\hline Acinetobacter species & $12(3 \%)$ & $10^{6}$ & 0 & 0 & \\
\hline Pseudomonas species & $24(5 \%)$ & $10^{7}$ & I (0.5\%) & $10^{6}$ & \\
\hline Bacillus species & $5(1 \%)$ & $10^{5}$ & I (0.5\%) & $10^{4}$ & \\
\hline $\begin{array}{l}\text { Propionibacterium } \\
\text { species }\end{array}$ & $3(1 \%)$ & $10^{6}$ & $2(1 \%)$ & $10^{6}$ & \\
\hline Candida species & $4(1 \%)$ & $10^{5}$ & $4(2 \%)$ & $10^{5}$ & \\
\hline
\end{tabular}

CNS = coagulase negative staphylococci, SD = Standard Deviation

At a six-week postal follow-up of the cases, 21 women (12\% of respondents) reported contacting health care providers because of recurrent symptoms and antibiotics had been prescribed for eight of them. Out of these eight women, five had previously received a course of antibiotic treatment for their initial symptoms. One further woman reported a breast abscess. There were no reports of infected infants in the case group. Of the 21 who contacted health services because of recurrent symptoms within six weeks, ten were positive for $S$. aureus. There were no increased odds for recurrence of symptoms when the bacterial counts were $\geq 10^{7} \mathrm{cfu} / \mathrm{L}$ for any of the five species.

\section{Discussion}

It was shown, somewhat surprisingly, that many women with potential pathogens in their breast milk, even at high bacterial counts, either recovered spontaneously from mastitis or did not have any symptoms of mastitis (as seen among control women). Furthermore, it was demonstrated that increasing bacterial counts did not influence the clinical manifestation of mastitis. The breast milk of women who were given antibiotics because of their symptoms, did not contain higher bacterial counts than those who were not given antibiotics. These results and the finding that so many healthy women harboured potential pathogens in their breast milk may indicate that the division of mastitis into infective or non-infective forms may not be practically feasible. Although only $15 \%$ of women

Table 3: Correlations between symptoms and bacterial counts in women with mastitis $(n=192)$

\begin{tabular}{|c|c|c|c|c|c|}
\hline \multicolumn{6}{|c|}{ Bacterial species } \\
\hline & CNS & Viridans streptococci & Staphylococcus aureus & Group B Streptococci & Enterococcus faecalis \\
\hline \multicolumn{6}{|l|}{ Symptoms } \\
\hline Fever & $\begin{array}{l}r=0.20 \\
p=0.06\end{array}$ & $\begin{array}{l}r=0.14 \\
p=0.21\end{array}$ & $\begin{array}{l}r=0.05 \\
p=0.72\end{array}$ & $\begin{array}{l}r=0.09 \\
p=0.63\end{array}$ & $\begin{array}{l}r=0.15 \\
p=0.62\end{array}$ \\
\hline Erythema & $\begin{array}{l}r=0.06 \\
p=0.44\end{array}$ & $\begin{array}{l}r=0.008 \\
p=0.93\end{array}$ & $\begin{array}{l}r=0.15 \\
p=0.16\end{array}$ & $\begin{array}{l}r=-0.21 \\
p=0.30\end{array}$ & $\begin{array}{l}r=0.24 \\
p=0.38\end{array}$ \\
\hline Unrelieved breast tension & $\begin{array}{l}r=-0.04 \\
p=0.64\end{array}$ & $\begin{array}{l}r=0.11 \\
p=0.30\end{array}$ & $\begin{array}{l}r=-0.01 \\
p=0.95\end{array}$ & $\begin{array}{l}r=-0.05 \\
p=0.75\end{array}$ & $\begin{array}{l}r=0.41 \\
p=0.11\end{array}$ \\
\hline Pain & $\begin{array}{l}r=-0.02 \\
p=0.90\end{array}$ & $\begin{array}{l}r=0.74 \\
p=0.43\end{array}$ & $\begin{array}{l}r=0.05 \\
p=0.62\end{array}$ & $\begin{array}{l}r=-0.24 \\
p=0.14\end{array}$ & $\begin{array}{l}r=0.42 \\
p=0.90\end{array}$ \\
\hline Severity Index & $\begin{array}{l}r=-0.01 \\
p=0.91\end{array}$ & $\begin{array}{l}r=0.07 \\
p=0.50\end{array}$ & $\begin{array}{l}r=0.09 \\
p=0.45\end{array}$ & $\begin{array}{l}r=-0.21 \\
p=0.18\end{array}$ & $\begin{array}{l}r=0.31 \\
p=0.30\end{array}$ \\
\hline
\end{tabular}

$r=$ Pearson's correlation coefficient, CNS = coagulase negative staphylococci 
Table 4: Bacterial findings in breast milk of i) women prescribed antibiotics on the basis of symptoms alone and ii) women who presented with or developed abscess during treatment

\begin{tabular}{|c|c|c|c|c|c|c|}
\hline & \multicolumn{6}{|c|}{ Concentrations of bacterial species expressed in cfu/L } \\
\hline & CNS & S. aureus & Viridans streptococci & Pneumococci & Group B streptococci & Group A streptococi \\
\hline \multicolumn{7}{|c|}{$\begin{array}{l}\text { Women prescribed } \\
\text { antibiotics on the basis of } \\
\text { their symptoms }\end{array}$} \\
\hline No.l & $10^{6}$ & & & & $10^{8}$ & \\
\hline No.2 & $10^{8}$ & $10^{5}$ & & & & \\
\hline No.3 & $10^{6}$ & & $10^{5}$ & & & \\
\hline No.4 & & $10^{4}$ & $10^{5}$ & & & \\
\hline No.5 & $10^{8}$ & $10^{8}$ & & & & \\
\hline No.6 & & Not quantified & & & & Not quantified \\
\hline \multicolumn{7}{|c|}{$\begin{array}{l}\text { No.7 No culture carried } \\
\text { out }\end{array}$} \\
\hline \multicolumn{7}{|c|}{$\begin{array}{l}\text { Women who presented } \\
\text { with or developed breast } \\
\text { abscess during treatment }\end{array}$} \\
\hline No.l & $10^{7}$ & & & & & \\
\hline No.2 & $10^{6}$ & $10^{7}$ & $10^{7}$ & & & \\
\hline No.3 & $10^{7}$ & $10^{7}$ & & & & \\
\hline No.4 & $10^{6}$ & $10^{4}$ & & & & \\
\hline No.5 & $10^{6}$ & $10^{7}$ & $10^{5}$ & & & \\
\hline No.6 & $10^{6}$ & & & $10^{6}$ & & \\
\hline No.7 & $10^{6}$ & $10^{6}$ & & & & \\
\hline
\end{tabular}

with mastitis were given antibiotics, most of them recovered spontaneously with few cases of recurrent symptoms within 6 weeks requiring antibiotic treatment.

The diagnostic criteria for mastitis used in this study consisted of clinical signs and symptoms, which are in the main subjective. This implies that the scope of illness reported in the case group may have been quite broad, ranging from mild to very severe. However, the $6 \%$ incidence of mastitis in the breastfeeding population was low compared to the range reported by WHO $(2.6 \%-33 \%)$, which suggests that the women in the RCT were correctly diagnosed. The incidence of $3.3 \%$ of breast abscess development in the group with mastitis can be compared to data from a recent study from Australia, which showed that $14.5 \%$ of breastfeeding women were treated with antibiotics and $2.9 \%$ of the women with mastitis developed an abscess [11]. Leukocyte counts have previously been used as a marker of infective mastitis [5]. However, it was not possible in the present study to measure leukocyte levels since the cases were originally included in a RCT of care interventions where measurement of infection was not the primary aim. Bacterial content in breast milk may vary over time and by geographical location and therefore the findings of this study may not be applicable to all communities.

Our analysis suggested that the two most abundant bacterial species or groups found, CNS and viridans strepto- cocci, were not linked to clinical mastitis; these are well established as major components of the resident skin or throat flora and possibly of importance for protection against pathogens [12]. Interestingly, Heikkilä and Saris found that human breast milk contains commensal bacteria that inhibit $S$. aureus and may prevent maternal breast infections [13]. Two potentially pathogenic species, $S$. aureus and GBS, were recovered more frequently in mastitis cases as compared to controls, indicating an active role in mastitis. In particular, $S$. aureus has earlier been reported as a primary causative organism in mastitis [1416] and might conceivably be expected to give rise to breast abscess. The breast milk samples of five of the seven women with a breast abscess was positive for $S$. aureus, but these figures are too small to allow any conclusions to be drawn. The inflammation in mastitis occurs in the connective tissue of the breast and for this reason causative organisms may be difficult to isolate from breast milk.

It was stated in a WHO review on mastitis that antibiotic treatment is indicated if either cell or bacterial colony counts are available and indicate infection or symptoms are severe from the beginning or a nipple fissure is visible or symptoms do not improve after 12-24 hours of improved milk removal [2]. If these criteria had been followed, many more than the $15 \%$ of cases, as reported here, would have received antibiotics. Reports from industrialised countries such as Australia [17-19] and USA $[20,21]$ have shown that $77 \%-97 \%$ of women with lac- 
tational mastitis are prescribed antibiotics. The findings of our study do not appear to support this extensive use of antibiotic treatment for mastitis during lactation. It is important for all communities to avoid imprudent use of antibiotics because of the spread of methicillin resistant $S$. aureus (MRSA) and other multi-resistant pathogens. It has also been considered that maternal antibiotic therapy might disturb the commensal flora of the upper airways in breastfed infants [22].

The major rationale for treatment of mastitis by antibiotics is to avoid the development of breast abscess. However, empirical evidence for a continuum from mastitis to abscess is not readily available and the WHO review suggests that breast abscess may occur seemingly spontaneously, irrespective of previous mastitis [2]. Nonetheless, lactational mastitis has the potential for serious sequelae such as breast abscess and in rare cases septicaemia [1] and if clinical signs and symptoms and bacterial culture of breast milk are unhelpful, we need to consider how to aid in the decision to prescribe antibiotics. In order to select which women will not recover without antibiotic treatment, it is necessary to maintain daily contacts with the women to assure that symptoms are subsiding. Although, as reported earlier [4] the mean number of contact days with a breastfeeding clinic was $5( \pm 2.9)$, it is important, in our opinion, that symptoms improve within 24 to 48 hours after initiation of care interventions. Scales to measure symptoms may assist clinicians in judging whether improvement has occurred. Continuity of care provider will also ensure that women are adequately treated. Those not improving will need a new consultation with a view to antibiotic treatment. At this time, results of bacterial culture may be of value for choice of antibiotic.

The frequent occurrence of GBS in both cases and healthy mothers was notable. GBS is a leading cause of serious infection in neonates [23] but no such infections were reported in the context of this study. Whether certain components of breast milk may protect infants and mothers from invasive GBS infection will be an important area for future research. Another avenue for investigation might be to consider why many women who harbour $S$. aureus do not develop mastitis. Knowledge of how often breast abscess occurs during lactation without any noticeable episode of preceding breast inflammation might also give us more understanding of the process. Well-designed RCTs of antibiotic therapy for treatment of lactational mastitis would help define the optimal level of such treatment for this group. New research could also include measurement of leukocyte levels.

\section{Conclusion}

Potentially pathogenic bacteria, often at high levels, were found in breast milk from both healthy donors and women with lactational mastitis. Increasing bacterial counts did not affect the clinical manifestation of mastitis, thus bacterial counts in breast milk may be of limited value in the decision to treat with antibiotics and results from bacterial culture of breast milk may be difficult to interpret. These results suggest that division of mastitis into infective and non-infective forms may not be practically feasible. Daily follow-up to measure the subsidence of symptoms can help identify those in need of antibiotic treatment.

\section{Competing interests}

The author(s) declare that they have no competing interests.

\section{Authors' contributions}

LJK, MLH-L, BWL and CS designed the study. AS and CS provided expert advice on collection of samples and interpretation of microbiological findings. Statistical analyses were carried out by LJK who drafted the manuscript. The manuscript was modified after discussions with MLH-L, BWL and CS.

\section{Acknowledgements}

This research was generously supported by the Stig and Ragna Gorthon Foundation, Helsingborg, Sweden. This is a non profit-making organisation for the promotion of health care research. Funds were provided for the first author to allow leave of absence to carry out the study.

\section{References}

I. Barbosa-Cesnik C, Schwartz K, Foxman B: Lactation mastitis. JAMA 2003, 289(13):1609-1612.

2. Mastitis: Causes and Management [http://www.who.int/childadolescent-health/New Publications/NUTRITION/ WHO FCH CAH 00 13.PDF]

3. Fetherston $\mathrm{C}$ : Mastitis in lactating women: physiology or pathology? Breastfeed Rev 200I, 9(I):5-12.

4. Kvist LJ, Hall-Lord M-L, Rydhstroem H, Wilde Larsson B: A randomised controlled trial in Sweden of acupuncture and care interventions for the relief of inflammatory symptoms of the breast during lactation. Midwifery 2007, 23(2): $184-195$.

5. Thomsen AC, Hansen K, Moller BR: Leukocyte counts and microbiologic cultivation in the diagnosis of puerperal mastitis. Am J Obstet Gynecol 1983, I 46(8):938-94I.

6. Thomsen AC, Espersen T, Maigaard S: Course and treatment of milk stasis, non-infectious inflammation of the breast, and infectious mastitis in nursing women. Am J Obstet Gynecol 1984, 149(5):492-495.

7. Matheson I, Aursnes I, Horgen M, Aabo O, Melby K: Bacteriological findings and clinical symptoms in relation to outcome in puerperal mastitis. Acta Obstet Gynecol Scand 1988, 67(8):723-726.

8. Aab O, Matheson I, Aursnes I, Horgen M, Lagerlv P, Melby K: Mastitis in general practice. Is bacteriological examination useful? Tidsskr Nor Laegeforen 1990, I I 0( I6):2075-2077.

9. Streiner DL, Norman GR: Health Measurement Scales. A Practical Guide to Their Development and Use Second edition. Oxford: Oxford University Press; 1995.

10. Kvist LJ, Hall-Lord M-L, Wilde Larsson B: A descriptive study of Swedish women with symptoms of breast inflammation during lactation and their perceptions of the quality of care given at a breastfeeding clinic. Int Breastfeed J 2007, 2:2.

II. Amir LH, Forster D, McLachlan H, Lumley J: Incidence of breast abscess in lactating women: report from an Australian cohort. BJOG 2004, I I I( I 2): I378-I38I. 
12. Isenberg DH, D'Amato R: Indigenous and pathogenic microorganisms of humans. In Manual of Clinical Microbiology 5th edition. Edited by: Balows A, Hausler WJ, Herrman KL, Isenberg H, Shadomy HJ. Washington, D.C.; ASM; 1991:2-14.

13. Heikkila MP, Saris PE: Inhibition of Staphylococcus aureus by the commensal bacteria of human milk. J Appl Microbiol 2003, 95(3):47|-478.

14. Osterman K, Rahm V-A: Lactation mastitis: bacterial cultivation of breast milk, symptoms, treatment and outcome. J Hum Lact 2000, 16(4):297-302.

15. Michie C, Lockie F, Lynn W: The challenge of mastitis. Arch Dis Child 2003, 88(9):8|8-82I.

16. Amir LH, Garland SM, Lumley J: A case-control study of mastitis: nasal carriage of Staphylococcus aureus. BMC Fam Pract 2006, 7:57.

17. Evans M, Heads J: Mastitis: incidence, prevalence and cost. Breastfeed Rev 1995, 3:65-7I.

18. Kinlay J, O'Connell DL, Kinlay S: Incidence of mastitis in breastfeeding women during the six months after delivery: a prospective study. Med J Aust 1998, 169(6):310-3/2.

19. Fetherston C: Management of lactation mastitis in a Western Australian cohort. Breastfeed Rev 1997, 5:13-19.

20. Foxman B, D'Arcy H, Gillespie B, Bobo JK, Schwartz K: Lactation mastitis: occurrence and medical management among 946 breastfeeding women in the United States. Am J Epidemiol 2002, I55(2): 103-II4.

21. Wambach KA: Lactation mastitis: a descriptive study of the experience. J Hum Lact 2003, 19(I):24-34.

22. Kummeling I, Stelma FF, Dagnelie PC, Snijders BE, Penders J, Huber $M$, van Ree R, van den Brandt PA, Thijs C: Early life exposure to antibiotics and the subsequent development of eczema, wheeze, and allergic sensitization in the first 2 years of life: the KOALA Birth Cohort Study. Pediatrics 2007, II (I):225-23I.

23. Law MR, Palomaki G, Alfirevic Z, Gilbert R, Heath P, McCartney C, Reid T, Schrag S: The prevention of neonatal group B streptococcal disease: a report by a working group of the Medica Screening Society. J Med Screen 2005, 12(2):60-68.

Publish with Biomed Central and every scientist can read your work free of charge

"BioMed Central will be the most significant development for disseminating the results of biomedical research in our lifetime. "

Sir Paul Nurse, Cancer Research UK

Your research papers will be:

- available free of charge to the entire biomedical community

- peer reviewed and published immediately upon acceptance

- cited in PubMed and archived on PubMed Central

- yours - you keep the copyright 